\title{
Crises, Crude oil and BRIC stock markets
}

\author{
Valeri Natanelov*a ${ }^{\mathrm{a}}$, Manoj Dora ${ }^{\mathrm{a}}$, Xavier Gellynck ${ }^{\mathrm{a}}$, and Guido Van Huylenbroeck ${ }^{\mathrm{a}}$ \\ ${ }^{a}$ Department of Agricultural Economics, Ghent University, Ghent, Belgium
}

\begin{abstract}
This study complements the debate on the linkages between crude oil and BRIC stock markets. The usage of the most recent data with daily frequency within a period of two economic crises makes this study very timely and its results valuable both for researchers and investors. The main focus of this study is the impact of crude oil price on dissimilar BRIC economies. The main results indicate linear cointegration of Chinese and Brazilian stock markets with crude oil prices, whereas in case of India and Russia threshold cointegration is present. The study also shows that India's BSE30 precedes crude oil futures, whereas China, Russia and Brazil have a bi-directional causality between the stock markets and crude oil prices.
\end{abstract}

Keywords - BRIC, crude oil, stock markets, cointegration

This study was partly financed by the Institute for the Promotion of Innovation through Science and Technology in Flanders (IWT-Vlaanderen)

*Corresponding author:

valeri.natanelov@ugent.be

Department of Agricultural Economics

Ghent University

Coupure links 653

9000 Ghent, Belgium

Tel.: 0032 (0)9 2645929

Fax: 0032 (0)9 2646246 


\section{Introduction}

While several studies have attempted to dissect the complex relationship between crude oil prices and stock markets, the final results and conclusions have failed to converge to a consensus (Basher \& Sadorsky, 2006; Maghyereh, 2004; Miller \& Ratti, 2009; Sadorsky, 1999). That being said, mulling over the economic rationale behind the potential relationship in this context seems sensible. Energy prices affect world economies and markets in many ways. Higher energy prices result in increased production and transportation costs both in the short- and long run. Furthermore, price changes of crude oil could be demand or supply driven and various scenarios could occur. When economies prosper and grow the demand for oil as the main energy commodity increases and thus its prices. In a situation like this it seems plausible that crude oil moves in parallel with stock prices. Under these circumstances even the causality seems evident. On the other hand, due to uncertainties and geopolitical events crude oil prices are subject to changes stemming from external shocks which in turn affect the speed of economic growth. In reality, the situation is more complex and nuanced and should be treated accordingly. Crude oil is the most traded commodity exceeding daily values of trillions which in addition to speculative opportunities in stock markets might result in a dynamic and entwined relationship. It is undeniable that the amount and speed of available information for markets participants have increased and improved, which might have an impact on such a relationship.

We focus on stock markets in Brazil, Russia, India and China or BRIC as coined by Jim O’Neil (2001). Since the characteristics of large emerging economies differ from wellestablished ones which might be used to shed more light on the issue. Consequently, the contrasts between the BRIC economies would allow us to distinguish changes and similarities: Brazil with its large scale ethanol production, Russia with large oil reserves and oil exports, India with its struggles after the economic reform of 1991, and China as the fastest growing major and second largest economy. According to IMF (2011), recently India is closing in on China with a yearly growth surpassing $10 \%$ in 2010, while Brazil and Russia enjoyed a yearly growth of $7 \%$ and 4\% respectively. The Energy Information Administration (EIA) (2011) reports that roughly $20 \%$ of the total annual oil demand in 2011 came from the BRIC countries. In terms of oil consumption Brazil is achieved self-sufficiency through combining investment in oil exploration and a significant ethanol production. Brazilian self-sufficiency and ethanol production in combination with limited refining capabilities create a complex dynamism of price influences of global energy, stock and agricultural markets. Historically a 
net exporter of crude oil, Russia exporting the largest volume in 2010 according to the International Energy Agency (IEA). The energy exports are of great importance to Russia's economy, making it exposed to fluctuations in world oil price. India, historically a net oil importer, has a production size of $1 \%$ of the global total while a demand of around $3 \%$ of the global total (IEA 2011). IEA's oil market report (2011) indicates that Chinese demand for oil comes close to $10 \%$ of the global total leaving a deficit of around $6 \%$ of the global total, making China one of the largest oil importers.

In this study we attempt to tackle these issues by a specific framework, allowing us to detect and distinguish linear relationships; a relationship between prices after a certain threshold; and potentially lack of parallel movement.:

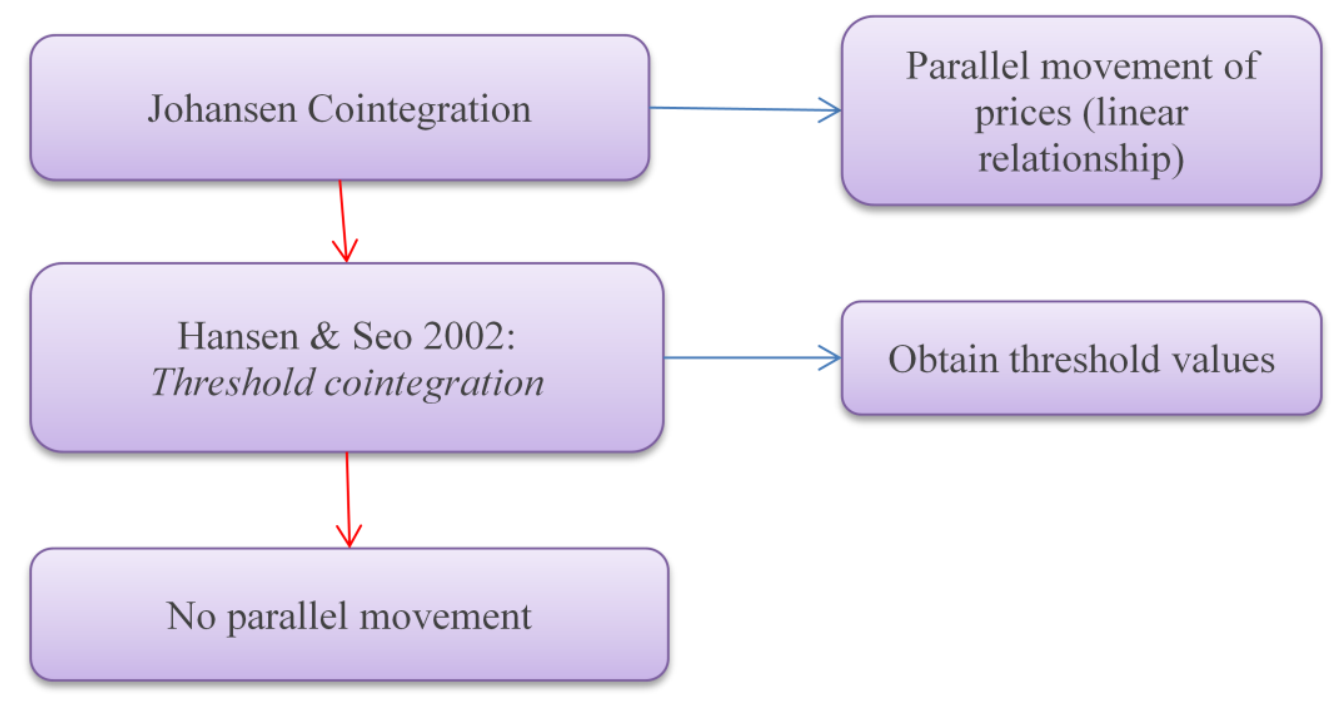

We use daily data between early January 2006 and late August 2011. Since the focus of the study is to analyze the relationship between crude oil prices and stock markets, the frequency of sampling is crucial for analysis in such a context. In addition to the above, our study allows us to analyze the impact of the financial crisis in 2008 and the current crisis consequently. Finally, a causality analysis may shed light on the direction of the relationship between crude oil and stock markets. To our knowledge, no previous study has made such an attempt within the context described above.

The paper is structured in the following manner: In the literature review section we attempt to offer a comprehensive overview of previous studies to outline the framework of our study. In the methodology section we discuss the techniques used for our analysis. In the 
following section we present and discuss the results. In the final part concluding remarks and recommendations are offered.

\section{Literature}

The pioneering work of James Hamilton (1983) opened the debate on the relation between the price of crude oil and macroeconomic variables such as GNP, inflation, unemployment. Recent studies focus on changes in the price of crude oil and its impact on fluctuations in stock prices. Research based on empirical studies found contradictory results about the relationship between stock prices and the price of crude oil. On the one hand, researchers pointed out a significant negative relation between crude oil price rise and stock prices (Basher \& Sadorsky, 2006; Ciner, 2001; Miller \& Ratti, 2009; Nandha \& Faff, 2008; Park \& Ratti, 2008; Sadorsky, 1999). On the other hand, studies also indicate insignificant or smaller effects of oil price fluctuations on stock prices (Blanchard \& Gali, 2008; Cologni \& Manera, 2005; Kilian, 2008).

Sadorsky (1999) using vector auto regression confirms that oil prices and oil price volatility both play important roles in affecting economic activity. The results suggest that changes in oil prices impact economic activity while changes in economic activity have little impact on oil prices. Impulse response functions show that oil price movements are crucial in explaining movements in stock returns. Papapetrou's (2001) empirical study suggests that oil prices significantly affect economic activity and employment. Oil price shocks explain a significant proportion of the fluctuations in output growth and employment growth. Ciner (2001) used nonlinear causality tests and found that oil shocks affect US stock index returns. More recently, Park and Ratti (2008) concluded that that oil price shocks have a statistically significant impact on real stock returns in the same month or within one month and that this result is robust to reasonable changes in the VAR model of variable order and inclusion of additional variables. Miller and Ratti (2009) studied the long-run relationship between crude oil and stock markets for six OECD countries and found that the stock market indices respond negatively to increases in the oil price in the long run. Kilian and Park (2009) developed a new methodology for understanding stock market fluctuations associated with oil price shocks. They documented that the response of U.S. real stock returns to oil price shocks differ substantially, depending on the underlying causes of the oil price increase. They argue that shocks to the production of crude oil are less important for understanding changes in stock prices than shocks to the global aggregate demand for industrial commodities or shocks to the precautionary demand for oil that reflect uncertainty about future oil supply shortfalls. Their 
analysis suggests that the traditional approach to thinking about oil price changes and stock prices must be rethought in a dynamic context.

Complementarily, a large body of literature suggests that crude oil prices have a statistically significant effect on economic activity (Adrangi, et al., 2001; Berument, et al., 2010; Brown \& Yücel, 2001; Costantini \& Martini, 2010; Fofana, et al., 2009; Hamilton, 2009a, 2009b; Hanabusa, 2009; Hsing, 2007; Huang, et al., 1996; Jayaraman \& Choong, 2009; Jiao \& Ma, 2006; Jones, et al., 2004b; Odusami, 2010; Oladosu, 2009; Papapetrou, 2001; Rafiq, et al., 2009; Reynolds \& Kolodziej, 2007; Zagaglia, 2010). Uri (1996) indicated the effect of changes in the price of crude oil on agricultural employment in the USA between 1947 and 1995 using Granger Causality. Lardic and Mignon (2008) studied the long-term relationship between oil prices and economic activity, proxies of GDP for the US, G7, Europe and Euro area economies. They found evidence for an asymmetric cointegration between oil prices and GDP indicating that rising oil prices seem to retard aggregate economic activity further than falling oil prices stimulate it. Correspondingly, He (2010) established a cointegration relationship between real futures crude oil prices and global economic activity, using the Kilian index. Furthermore, changing energy prices seem to affect commodities markets through macro-economic effects (Gohin \& Chantret, 2010; Natanelov, et al., 2011). The relationship between energy and economic activity and crude oil prices with commodity markets may complete the circle and strengthen the relationship especially in BRIC countries where commodities encompass an important part of their economies and might cause significant spillover effects.

The growing importance of emerging markets in the global economy brought the attention of researchers to study the relationship between crude oil prices and stocks market returns in the emerging market context. Basher \& Sadorsky (2006) found that there is a significant but negative relationship between oil price movements and stock returns in 21 emerging stock markets. Using VAR models, Ono (2011) examined the impact of oil prices on real stock returns for BRIC countries. The results of his study suggest that for China, India and Russia stock returns respond positively to the oil price indicators, however, Brazil does not show any significant responses. The study also pointed out that there are significant asymmetric effects of oil price fluctuation in the Indian context. Using the variance decomposition analysis the study concludes that the oil price shocks to volatility in real stock returns is large and significant for China and Russia. Bhar \& Nikolova (2009) found that the level of impact of oil prices on stock price returns and volatility depends on the BRIC countries' dependency on 
the oil import and export. Being Brazil the net exporter of oil which implies higher export revenues make Brazil more susceptible to changes in global oil prices. On the other hand, India and China are net importers. Their study found that changes in oil price affect the conditional volatility of stock price returns in the Indian and Chinese markets.

This paper complements the above studies through the investigation of direct linkages between crude oil and BRIC stock indices. In addition, our study analyses may shed light on contrasting movements between the BRIC countries. The usage of the most recent data with daily frequency within a period of 2 economic crises makes the study very timely and prominent. Natanelov (2011) indicates that linkages between markets are a temporal concept and should be treated accordingly. Utilizing the most current data, this study may contribute to the literature by studying how the relationship between crude oil and stock markets evolves while being subject to two consequent crises. Within this context, contrasting effects on dissimilar BRIC economies can be studied. The causality analysis may offer more nuanced results given the daily frequency of the data which captures short-run dynamics.

\section{Methodology}

\section{Johansen co-integration}

In the case of non-stationarity of the time-series, cointegration provides appropriate statistical techniques to investigate if there is a statistically significant relationship between the non- stationary time-series. Therefore we test the price series for stationarity in levels and in first differences. In time series econometrics it is said that prices are integrated of order one denoted by $P_{t} \sim I(1)$ and prices are integrated of order zero denoted by $\Delta P_{t} \sim I(0)$. When price series are found to be non-stationary in levels but stationary in first differences, cointegration tests may be applied. The cointegration procedure is based upon an unrestricted vector autoregressive (VAR) model specified in error-correction form (Johansen, 1988; Johansen \& Juselius, 1990):

$$
\Delta X_{t}=\Pi X_{t-1}+\sum_{i=1}^{k-1} \Gamma_{i} \Delta X_{t-i}+\Phi D_{t}+v_{t}
$$

Where $\mathrm{X}_{\mathrm{t}}$ includes all $\mathrm{n}$ variables of the model, which are $\sim I(1)$, the $\Pi, \Gamma_{i}$ and $\Phi$ are parameter matrices to be estimated. $D_{t}$ is a vector with deterministic elements (constant, 
trend and dummy) and $v_{t}$ is a vector of random errors which follow a Gaussian white noise process. Equation (1) implies that there can never be any relationship between a variable with a stochastic trend, $I(1)$ and a variable without a stochastic trend, $I(0)$. So, if $\Delta P_{t} \sim I(0)$, then $\Pi$ will be a matrix of zeros, except when a linear combination of the variables in $P_{t}$ is stationary. The Johansen test for cointegration evaluates the rank (r) of the matrix $\Pi$. If $r=0$, all variables are $\mathrm{I}(1)$ and thus not cointegrated. In case of $0<\mathrm{r}<\mathrm{N}$, there exist $\mathrm{r}$ cointegrating vectors. In the third case, if $\mathrm{r}=\mathrm{N}$ all the variables are $\mathrm{I}(0)$ and thus stationary, and any combination of stationary variables will be stationary. $\Pi$ represents the long response matrix and is defined as the product of two matrices: $\alpha$ and $\beta$, of dimension ( $\mathrm{g} \times \mathrm{r}$ ) and ( $\mathrm{r} \times \mathrm{g}$ ) respectively. The $\beta$ matrix contains the long-run coefficients of the cointegrating vectors; $\alpha$ is known as the adjustment parameter matrix and is similar to an error correction term. The linear combination(s) $\beta^{\prime} \mathrm{x}_{\mathrm{t}-\mathrm{k}}$ of this matrix will be $\mathrm{I}(0)$ in the case where the times series are cointegrated. In other words, if rank of $\Pi=\mathrm{r}=\mathrm{K}$, the variables in levels are stationary, meaning that no integration exist; if $\operatorname{rank} \Pi=\mathrm{r}=0$, that means all the elements in the adjustment matrix have zero value. Therefore, none of the linear combinations are stationary. According to the Granger representation theorem (Engle \& Granger, 1987), there are $r$ cointegrating vectors or $r$ stationary linear combinations of the variables when $K>0$ and rank of $\Pi(\mathrm{r})<\mathrm{K}$. The Johansen cointegration method estimates the $\Pi$ matrix through an unrestricted VAR and tests whether one can reject the restriction implied by the reduced rank of $\Pi$. Two methods of testing for reduced rank of $\Pi$ are the trace test and the maximum eigenvalue, respectively:

$$
\begin{gathered}
\lambda_{\text {trace }}=-T \sum_{i=r+1}^{n} \ln \left(1-\hat{\lambda}^{2}{ }_{i}\right) \\
\lambda_{\max }(r, r+1)=-T \ln \left(1-\lambda_{r+1}\right)
\end{gathered}
$$

Where $\lambda_{i}$ is the estimated value of the ordered eigenvalues obtained from the estimated matrix and $\mathrm{T}$ is the number of the observations after the lag adjustment. The trace statistics test the null hypothesis, meaning that the number of distinct cointegrating vectors (r) is less than or equal to $r$ against a general alternative. The maximal eigenvalue tests the null hypothesis, meaning that the number of cointegrating vectors is $r$ against the alternative of $r+1$ cointegrating vectors. 


\section{Causality from the vector error correction model (VECM)}

The existence of cointegration in the bi-variate relationship implies Granger causality at least in one direction which under certain restrictions can be tested within the framework of Johansen cointegration by the Wald test (Dolado \& Lütkepohl, 1996; Mosconi \& Giannini, 1992). If the $\alpha$ matrix in the cointegration matrix ( $\Pi$ ) has a complete column of zeros, no causal relationship exists since no cointegrating vector appears in that particular block. Pairwise causal relationships can be represented through the following equation:

$$
\begin{aligned}
{\left[\begin{array}{l}
\Delta X_{1, t} \\
\Delta X_{2, t}
\end{array}\right]=\left[\begin{array}{l}
\mu_{1} \\
\mu_{2}
\end{array}\right] } & +\left[\begin{array}{l}
\alpha_{1} \\
\alpha_{2}
\end{array}\right]\left(X_{1, t-1}-\beta X_{2, t-1}\right)+A_{1}\left[\begin{array}{l}
\Delta X_{1, t-1} \\
\Delta X_{2, t-1}
\end{array}\right]+\cdots A_{k}\left[\begin{array}{l}
\Delta X_{1, t-k} \\
\Delta X_{2, t-k}
\end{array}\right] \\
& +\left[\begin{array}{l}
v_{1 t} \\
v_{2 t}
\end{array}\right](4)
\end{aligned}
$$

Parameters contained in matrices $A_{k}$ measure the short run causality relationship, while $\beta$ is the cointegrating parameter that characterizes the long-run equilibrium relationship between the series. Through equation (4), three possibilities for a long-run causality may be identified, i) $\alpha_{1} \neq 0, \alpha_{2} \neq 0$; ii) $\alpha_{1}=0, \alpha_{2} \neq 0$, and iii) $\alpha_{1} \neq 0, \alpha_{2}=0$. The first case indicates a bi-directional causality, while the second and third imply uni-directional causality.

To analyze for short-run causality we apply the Wald test with the null hypothesis that the joint contribution of the lags of endogenous variables is equal to zero. If the null cannot be rejected it implies that the respective endogenous variables can be treated as exogenous in the system. In case of bi-variate models, the Johansen cointegration equation (1) can be rewritten as:

$$
\begin{aligned}
& \Delta \mathrm{X}_{1, \mathrm{t}=\mu_{1}}+\sum_{\mathrm{i}=1}^{\mathrm{k} 1} \beta_{\mathrm{i}} \Delta \mathrm{X}_{1, \mathrm{t}-\mathrm{i}}+\sum_{\mathrm{j}=1}^{\mathrm{k} 2} \beta_{\mathrm{j}} \Delta \mathrm{X}_{2, \mathrm{t}-\mathrm{j}}+\alpha_{1} \mathrm{ECT}_{\mathrm{t}-1}+\varepsilon_{\mathrm{t}, 1} \\
& \Delta \mathrm{X}_{2, \mathrm{t}=\mu_{2}}+\sum_{\mathrm{i}=1}^{\mathrm{k} 1} \beta_{\mathrm{i}} \Delta \mathrm{X}_{1, \mathrm{t}-\mathrm{i}}+\sum_{\mathrm{j}=1}^{\mathrm{k} 2} \beta_{\mathrm{j}} \Delta \mathrm{X}_{2, \mathrm{t}-\mathrm{j}}+\alpha_{2} \mathrm{ECT}_{\mathrm{t}-1}+\varepsilon_{\mathrm{t}, 1}
\end{aligned}
$$

where $X_{1, t}$ and $X_{2, t}$ are time series (of prices) and ECT is the error correction term. We test the short run causality through equations (5) and (6), by examining the significance of all lagged dynamic terms. 


\section{Threshold Cointegration}

Threshold cointegration allows for the extension of the classical case of linear cointegration. The adjustment from equilibrium may take place only after the deviation exceeds a certain threshold. Through the perspective of economic theory, the assumption of non-linearity may not be valid in the presence of transaction costs (Balke \& Fomby, 1997) or certain policies (Lo \& Zivot, 2001) that may influence and buffer markets until the deviations exceed a certain threshold. Threshold cointegration analysis may indicate that once a threshold level is surpassed, prices will adjust back to a long-run equilibrium.

Following Hansen and Seo (2002) a two-regime threshold cointegration model takes the form

$$
\Delta \mathrm{X}_{\mathrm{t}}=\left\{\begin{array}{lll}
\mathrm{B}^{\prime}{ }_{1} \mathrm{X}_{\mathrm{t}}+\mu_{\mathrm{t}} & \text { if } \beta^{\prime} \mathrm{X}_{\mathrm{t}-1} \leq \gamma \\
\mathrm{B}^{\prime}{ }_{2} \mathrm{X}_{\mathrm{t}}+\mu_{\mathrm{t}} & \text { if } \quad \beta^{\prime} \mathrm{X}_{\mathrm{t}-1}>\gamma
\end{array}\right.
$$

where $\gamma$ represents the threshold parameter. Equation (7) can be written as

$$
\Delta \mathrm{X}_{\mathrm{t}}=\mathrm{B}_{1}^{\prime} \mathrm{X}_{\mathrm{t}-1}(\beta) \mathrm{d}_{1 \mathrm{t}}(\beta, \gamma)+\mathrm{B}_{2}^{\prime} \mathrm{X}_{\mathrm{t}-1}(\beta) \mathrm{d}_{2 \mathrm{t}}(\beta, \gamma)+\mu_{\mathrm{t}}
$$

with $\mathrm{d}_{1 \mathrm{t}}(\beta, \gamma)=1$ (if $\left.\beta^{\prime} \mathrm{X}_{\mathrm{t}-1} \leq \gamma\right)$ and $\mathrm{d}_{2 \mathrm{t}}(\beta, \gamma)=1 \quad$ if $\left.\beta^{\prime} \mathrm{X}_{\mathrm{t}-1}>\gamma\right)$ and with coefficient matrices $B_{1}$ and $B_{2}$ determining the dynamics in the two regimes. Besides the coingrating vector $\beta$, all coefficients are permitted to switch between the two regimes.

Hansen and Seo note that the threshold effect is only consistent if $0<P\left(\beta^{\prime} \mathrm{X}_{\mathrm{t}-1} \leq \gamma\right)<$ 1 , otherwise the model would reduce to a linear cointegration model. This constraint is imposed by assuming

$$
\pi_{0} \leq \mathrm{P}\left(\beta^{\prime} \mathrm{X}_{\mathrm{t}-1} \leq \gamma\right) \leq 1-\pi_{0}
$$

where $\pi_{0}>0$ is a trimming parameter. In the empirical application $\pi_{0}=0.05$ to ensure sufficient sample variation for every alternative of $\gamma$. The estimation of model (8) is conducted through maximum likelihood, under the assumption of iid Gaussian errors. 


\section{Empirical results and discussion}

The data used in the empirical analysis comprises daily prices of crude oil and stock indices of the BRIC countries: BVSP; RTS; BSE30; and CSI300 index respectively, starting 10 January 2006 until 28 August 2011. We use West Texas Intermediate (WTI), traded at the New York Mercantile Exchange (NYMEX), as a proxy for the global crude oil price. To account for the problem of comparing disparate price units, the data is indexed based on the price of January 2006 for each time series. Figure 1 illustrates the movement of the time series. The eye catcher if figure 1 is without a doubt China's remarkable growth which is expressed in the movements of its main stock index.

To determine whether the series are stationary, the Augmented Dickey-Fuller (ADF) test and the Phillips-Perron (PP) test are carried out. For time series the tests point to the existence of one unit root I(1). Thus, the difference of each time series can be regarded as stationary. Detailed results are presented in Table 1. In order to identify a possible influence of crude oil price on various stock indices, each time series was paired with crude oil price, providing us with 4 bivariate systems. Since the time series are integrated in the same order, cointegration techniques can be used to determine whether a stable long-run relationship exists between each pair. Johansen's tests for cointegration are performed. The VAR specification is estimated by applying one to 20 lags. As we utilize daily frequencies a potential lag of up to one month (i.e. 20 working days) has been noticeable. The Akaike Information Criterion (AIC) was utilized to select optimal lag length. Consequently the inverse root of AR characteristic polynomial is evaluated to confirm a proper lag selection for each bi-bariate system. The results for China and Brazil indicate that CSI300 and BVSP series are cointegrated with crude oil. This confirms the fact that oil prices respond to economic fundamentals like real economic activity but also to movements in emerging stock prices (Basher \& Sadorsky, 2006).

In case of India's stock index, BSE30, we find cointegration only with trace statistics of Model 1. Even though a relationship of Russia's main stock index, RTS, with crude oil cannot be rejected, the statistics seem to indicate 2 cointegrating vectors which seems unlikely for a bi-variate system with I(1). These results from emerging markets are aligned with the literature (Basher \& Sadorsky, 2006; Jonathan, 2000; Tang \& Shum, 2003). The asymmetries and inconsistent test statistics for the Russian and Indian oil and stock market price relationship attributed to each country's complex economic policies and structural breaks (Ono, 2011). 
Table 3 presents the speed of adjustment from the estimated Johansen VAR (restricted VAR model); t-tests for the cointegrating vector and the speed of adjustment. The relatively small parameter estimate $(\beta)$ of CSI300 and crude oil implies a weak link between China's main stock market index and crude oil prices. As stated in the introduction section, China is closely competing with the US as the main importer and consumer of crude oil. Taken that into account the results in Table 3 seem to be contradictory. Though, the so-called Beijing's Oil Diplomacy, a robust risk management strategy, uses trade agreements and acquisitions of oil interests in Russia, Iran, Central Asia, Venezuela and several others to support China's thirst for crude oil. In case of India and Brazil the relationship appears relatively stronger.

Turning to our VECM results, the ECT estimates for all bi-variate systems are relatively small, except of CSI300, which implies limited deviations from the cointegrating relationship. These results confirm a close relationship between the 3 bi-variate systems.

Once cointegration between time series is established it is of interest to analyze for causality of each cointegrating pair. Long run causality from the estimated Johansen VECM is analyzed through a likelihood ratio (LR) test by restricting the disequilibrium error term. Table 4 presents the results of these tests. The findings indicate that India's BSE30 precedes crude oil futures. In case of CSI300, RTS, and BSP-pairs we find a bi-directional causality.

Since the linear cointegration results for India and Russia imply asymmetries we implement TVECM for these two bivariate systems. Figures 2 and 3 show the results for BSE30 and RTS-crude oil pair respectively. The results indicate existence of threshold cointegration with $90 \%$ and $95 \%$ confidence level and the threshold parameter $\gamma$ is 0.16 and 0.25 respectively. Furthermore, since the results indicate asymmetries we estimate parameters $\beta$ with our TVECM. In case of Crude oil- BSE30 system, the estimate is close to the estimation from the linear model, namely 0.79 . For the Russian model the results indicate a $\beta$ estimate close to 1 .

\section{Conclusion}

The result of the study provides a better understanding of the dynamic relationship between crude oil prices and stock market returns among BRIC countries in the middle of two financial crises. The findings of this paper supports the hypothesis that fluctuations in stock prices respond to movements of crude oil prices. However, the degree and dimension of interaction varies substantially among countries. This may be attributed to the country specific 
factors such as China's remarkable economic growth, India's regulated oil sector, Russia's oil reserves and Brazil's steady growth. Through modern time series methodologies we have indicated that Chinese and Brazilian stock markets are moving in parallel with crude oil. Furthermore, the relationship between Chinese stocks and crude oil prices seems to be relatively weak, which can be attributed to China's vigorous risk management strategy, diversification of import-channels and acquisition of crude oil assets in various regions. Brazil's crude oil self-sufficiency and possibility of ethanol substitutability seems to buffer any change in relationships between crude oil prices and stock returns throughout the two crises. In addition, Brazil's position as large agricultural producer in a period of historically high prices in combination with its large ethanol production capability creates a stable relationship between crude oil and stock returns. For the Indian case, the results point to the heterogeneity of the crises. Pre-2008-crisis, the price relationship is unbalanced and distorted, while during the current crisis the relationship is stronger and more balanced. This should not come as a surprise as India has seen a remarkable growth of $6.8 \%$ and $10.4 \%$ in 2009 and 2010 respectively (IMF, 2011). Russia exhibits a similar pattern of changing relationship, however the causes are of a more negative nature. Pre-2008-crisis, the markets seem to be only partially influenced by one and other. The results indicate that much of Russia's non-oil related economic activity has been crushed during the 2008 crises, and that the relationship between Russian stock returns and crude oil prices became almost perfectly parallel. These results are consistent with other empirical papers that find country specific factors influences relationship between crude oil price and stock index movement(Basher \& Sadorsky, 2006; Cheung \& Ng, 1998; Jones, et al., 2004a; Nandha \& Faff, 2008) The findings of this study have a number of policy implications and also pave the way for further research in this topic. Stock index not only respond to demand and supply of the crude oil price but also to economic fundamentals of the country. The investors must consider the country specific macro indicators and economic policies before making any decision to invest. For policy makers as well, it is important to look into the sensitivity of crude oil and stock index relation with respect to all policy changes. Future research will look into the changes in the composition of the BRIC stock-market indices and the effect on the crude oil relationship. Furthermore, the inclusion of other economic variables, such as inflation, interest rates, and employment could offer a better understanding of the interaction between oil and stock price in BRIC countries. Another potential research question could be the interaction between core stock prices of individual countries and crude oil price to understand sector specific influences. 


\section{References}

Adrangi, B., Chatrath, A., Dhanda, K. K., \& Raffiee, K. (2001). Chaos in oil prices? Evidence from futures markets. Energy Economics, 23(4), 405-425.

Antonio, Narzo, F. D., Aznarte, J. L., \& Stigler, M. (2009). tsDyn: Time series analysis based on dynamical systems theory.

Balke, N. S., \& Fomby, T. B. (1997). Threshold cointegration. International Economic Review, 38(3), 627-645.

Basher, S. A., \& Sadorsky, P. (2006). Oil price risk and emerging stock markets. Global Finance Journal, $17(2), 224-251$.

Berument, M. H., Ceylan, N. B., \& Dogan, N. (2010). The Impact of Oil Price Shocks on the Economic Growth of Selected MENA Countries. Energy Journal, 31(1), 149-176.

Bhar, R., \& Nikolova, B. (2009). Oil prices and equity returns in the BRIC countries. The World Economy, 32(7), 1036-1054.

Blanchard, O. J., \& Gali, J. (2008). The macroeconomic effects of oil price shocks: why are the 2000s so different from the 1970s?. Massachusetts Institute of Technology, Department of Economics. In: Working Paper 07-21, August 18, 2007, revised: March 25.

Brown, S., P. A. , \& Yücel, M., K. . (2001). Energy prices and aggregate economic activity: an interpretive survey. In: Federal Reserve Bank of Dallas.

Cheung, Y. W., \& Ng, L. K. (1998). International evidence on the stock market and aggregate economic activity. Journal of Empirical Finance, 5(3), 281-296.

Ciner, C. (2001). Energy shocks and financial markets: nonlinear linkages. Studies in Nonlinear Dynamics \& Econometrics, 5(3), 3.

Cologni, A., \& Manera, M. (2005). Oil Prices, Inflation and Interest Rates in a Sstructural Cointegrated VAR Model for the G-7 Countries.

Costantini, V., \& Martini, C. (2010). The causality between energy consumption and economic growth: A multi-sectoral analysis using non-stationary cointegrated panel data. Energy Economics, 32(3), 591-603.

Dolado, J. J., \& Lütkepohl, H. (1996). Making wald tests work for cointegrated VAR systems. Econometric Reviews, 15(4), 369-386.

Engle, R. F., \& Granger, C. W. J. (1987). Co-integration and Error Correction: Representation, Estimation, and Testing. Econometrica, 55(2), 251-276.

Fofana, I., Chitiga, M., \& Mabugu, R. (2009). Oil prices and the South African economy: A macromeso-micro analysis. Energy Policy, 37(12), 5509-5518.

Gohin, A., \& Chantret, F. (2010). The long-run impact of energy prices on world agricultural markets: The role of macro-economic linkages. Energy Policy, 38(1), 333-339.

Hamilton, J. D. (1983). Oil and the Macroeconomy since World War II. Journal of Political Economy, 91(2), 228-248.

Hamilton, J. D. (2009a). Causes and Consequences of the Oil Shock of 2007-08. Brookings Papers on Economic Activity(1), 215-283.

Hamilton, J. D. (2009b). Understanding Crude Oil Prices. Energy Journal, 30(2), 179-206.

Hanabusa, K. (2009). Causality relationship between the price of oil and economic growth in Japan. Energy Policy, 37(5), 1953-1957.

Hansen, B. E., \& Seo, B. (2002). Testing for two-regime threshold cointegration in vector errorcorrection models. Journal of Econometrics, 110(2), 293-318.

He, Y., Wang, S., \& Lai, K. K. (2010). Global economic activity and crude oil prices: A cointegration analysis. Energy Economics, 32(4), 868-876.

Hsing, Y. (2007). Impacts of higher crude oil prices and changing macroeconomic conditions on output growth in Germany International Research Journal of Finance and Economics(11).

Huang, R. D., Masulis, R. W., \& Stoll, H. R. (1996). Energy shocks and financial markets. Journal of Futures Markets, 16(1), 1-27.

IMF. (2011). Global prospects and policies. Global Outlook. 
Jayaraman, T. K., \& Choong, C. K. (2009). Growth and oil price: A study of causal relationships in small Pacific Island countries. Energy Policy, 37(6), 2182-2189.

Jiao, F. Y., \& Ma, J. (2006). Energy prices and aggregate economic activity: evidence from China. Proceedings of the 2006 International Conference on Management Science \& Engineering (13th), Vols 1-3, 1917-1922.

Johansen, S. (1988). Statistical-Analysis of Cointegration Vectors. Journal of Economic Dynamics \& Control, 12(2-3), 231-254.

Johansen, S., \& Juselius, K. (1990). Maximum-Likelihood-Estimation and Inference on Cointegration with Applications to the Demand for Money. Oxford Bulletin of Economics and Statistics, 52(2), 169-210.

Jonathan, F. (2000). On the conditional relationship between beta and return in international stock returns. International Review of Financial Analysis, 9(3), 235-245.

Jones, D. W., Leiby, P. N., \& Paik, I. K. (2004a). Oil price shocks and the macroeconomy: what has been learned since 1996. ENERGY JOURNAL-CAMBRIDGE MA THEN CLEVELAND OH-, 25(2), 132.

Jones, D. W., Leiby, P. N., \& Paik, I. K. (2004b). Oil price shocks and the macroeconomy: What has been learned since 1996. Energy Journal, 25(2), 1-32.

Kilian, L. (2008). A comparison of the effects of exogenous oil supply shocks on output and inflation in the $\mathrm{G} 7$ countries. Journal of the European Economic Association, 6(1), 78-121.

Kilian, L., \& Park, C. (2009). THE IMPACT OF OIL PRICE SHOCKS ON THE US STOCK MARKET*. International Economic Review, 50(4), 1267-1287.

Lardic, S., \& Mignon, V. (2008). Oil prices and economic activity: An asymmetric cointegration approach. Energy Economics, 30(3), 847-855.

Lo, M. C., \& Zivot, E. (2001). Threshold cointegration and nonlinear adjustment to the law of one price. Macroeconomic Dynamics, 5(4), 533-576.

Mackinnon, J. G. (1996). Numerical distribution functions for unit root and cointegration tests. Journal of Applied Econometrics, 11(6), 601-618.

Maghyereh, A. (2004). Oil price shocks and emerging stock markets: A generalized VAR approach. International Journal of Applied Econometrics and Quantitative Studies, 1(2), 27-40.

Miller, J. I., \& Ratti, R. A. (2009). Crude oil and stock markets: Stability, instability, and bubbles. Energy Economics, 31(4), 559-568.

Mosconi, R., \& Giannini, C. (1992). Noncausality in Cointegrated Systems - Representation Estimation and Testing. Oxford Bulletin of Economics and Statistics, 54(3), 399-417.

Nandha, M., \& Faff, R. (2008). Does oil move equity prices? A global view. Energy Economics, 30(3), 986-997.

Natanelov, V., Alam, M. J., McKenzie, A. M., \& Van Huylenbroeck, G. (2011). Is there co-movement of agricultural commodities futures prices and crude oil? Energy Policy, 39(9), 4971-4984.

Newey, W. K., \& West, K. D. (1994). Automatic Lag Selection in Covariance-Matrix Estimation. Review of Economic Studies, 61(4), 631-653.

O'Neill, J. (2001). Building Better Global Economic BRICs. Global Economics Paper, 66.

Odusami, B. O. (2010). To consume or not: How oil prices affect the comovement of consumption and aggregate wealth. Energy Economics, 32(4), 857-867.

Oladosu, G. (2009). Identifying the oil price-macroeconomy relationship: An empirical mode decomposition analysis of US data. Energy Policy, 37(12), 5417-5426.

Ono, S. (2011). Oil Price Shocks and Stock Markets in BRICs. The European Journal of Comparative Economics, 8(1), 29-45.

Papapetrou, E. (2001). Oil price shocks, stock market, economic activity and employment in Greece. Energy Economics, 23(5), 511-532.

Park, J., \& Ratti, R. A. (2008). Oil price shocks and stock markets in the US and 13 European countries. Energy Economics, 30(5), 2587-2608.

Rafiq, S., Salim, R., \& Bloch, H. (2009). Impact of crude oil price volatility on economic activities: An empirical investigation in the Thai economy. Resources Policy, 34(3), 121-132. 
Reynolds, D. B., \& Kolodziej, M. (2007). Institutions and the supply of oil: A case study of Russia. Energy Policy, 35(2), 939-949.

Sadorsky, P. (1999). Oil price shocks and stock market activity. Energy Economics, 21(5), 449-469.

Tang, G. Y. N., \& Shum, W. C. (2003). The conditional relationship between beta and returns: recent evidence from international stock markets. International Business Review, 12(1), 109-126.

Uri, N. D. (1996). Changing crude oil price effects on US agricultural employment. Energy Economics, $18(3), 185-202$.

Zagaglia, P. (2010). Macroeconomic factors and oil futures prices: A data-rich model. Energy Economics, 32(2), 409-417. 


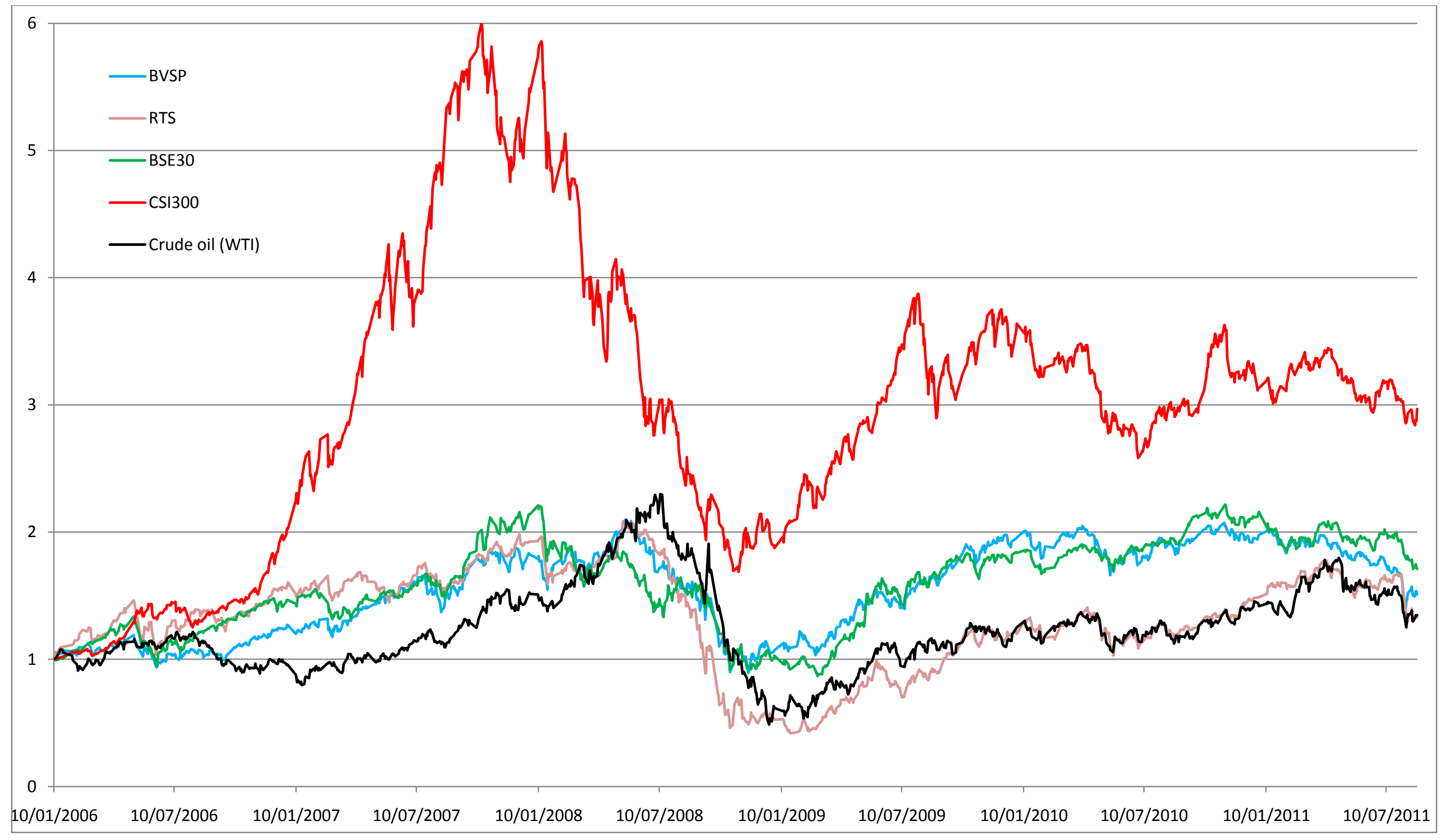

Figure 1. Indexed daily price evolution between 10 January, 2006 and 25 August, 2011 
Hansen and Seo test of linear versus threshold cointegration
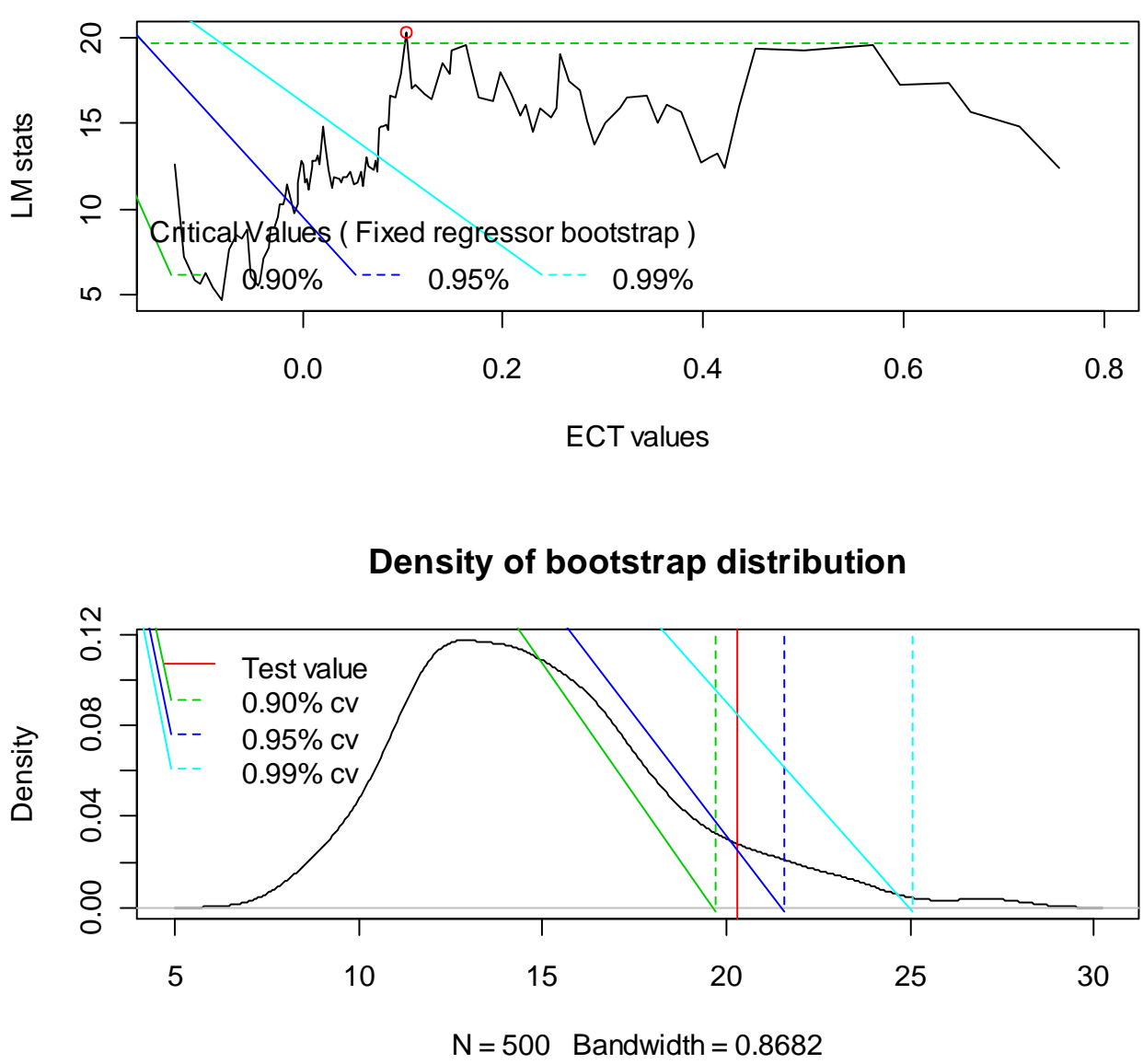

Grid Search
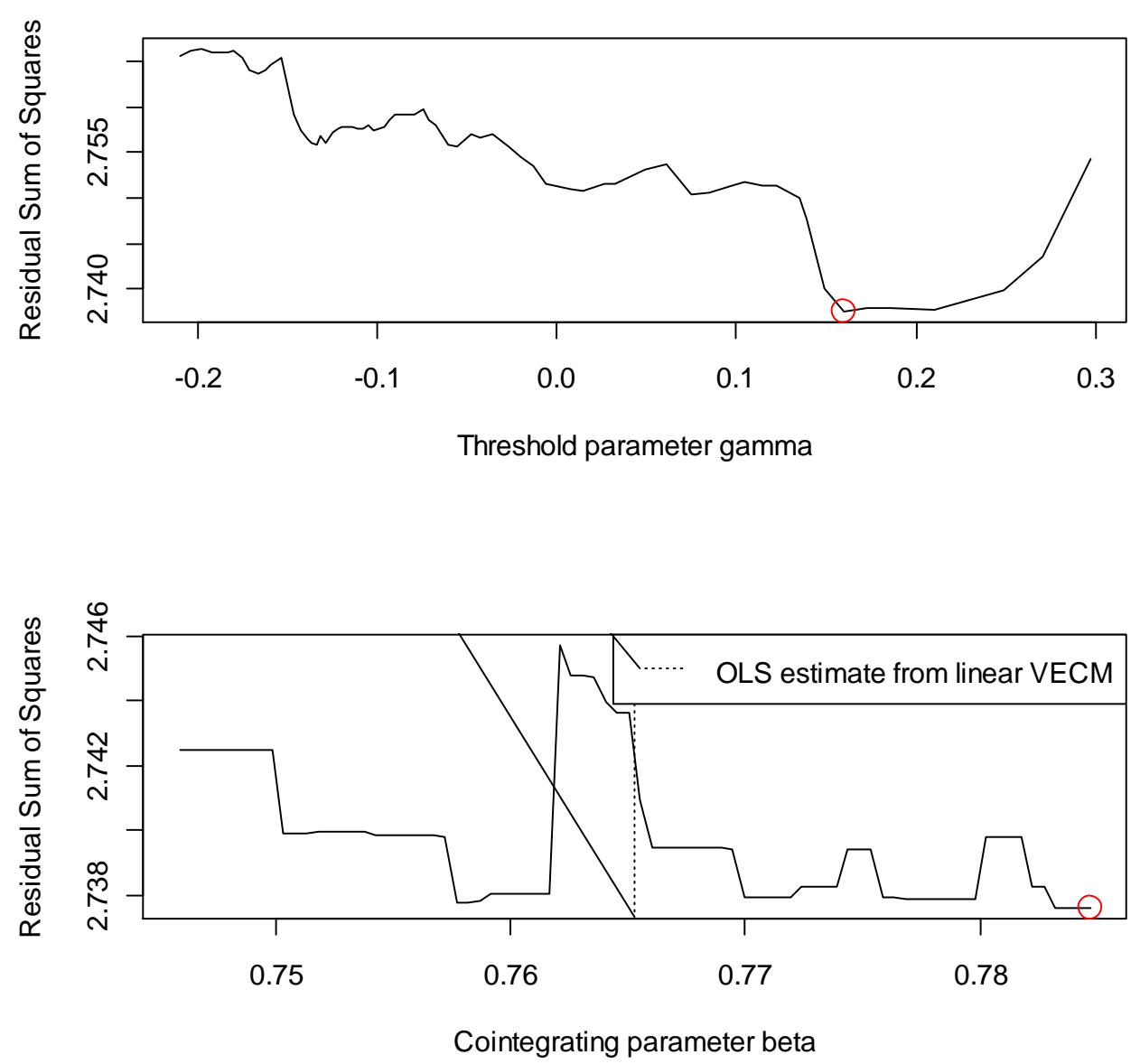

Figure 2: Testing Crude oil-BSE30 with TVECM (Antonio, et al., 2009; Hansen \& Seo, 2002) 
Hansen and Seo test of linear versus threshold cointegration

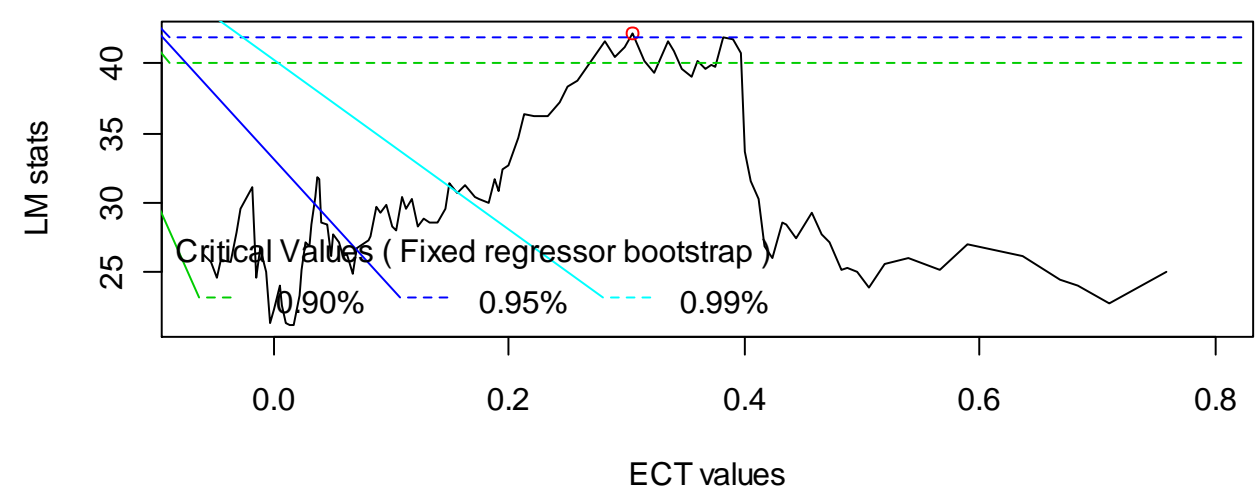

\section{Density of bootstrap distribution}

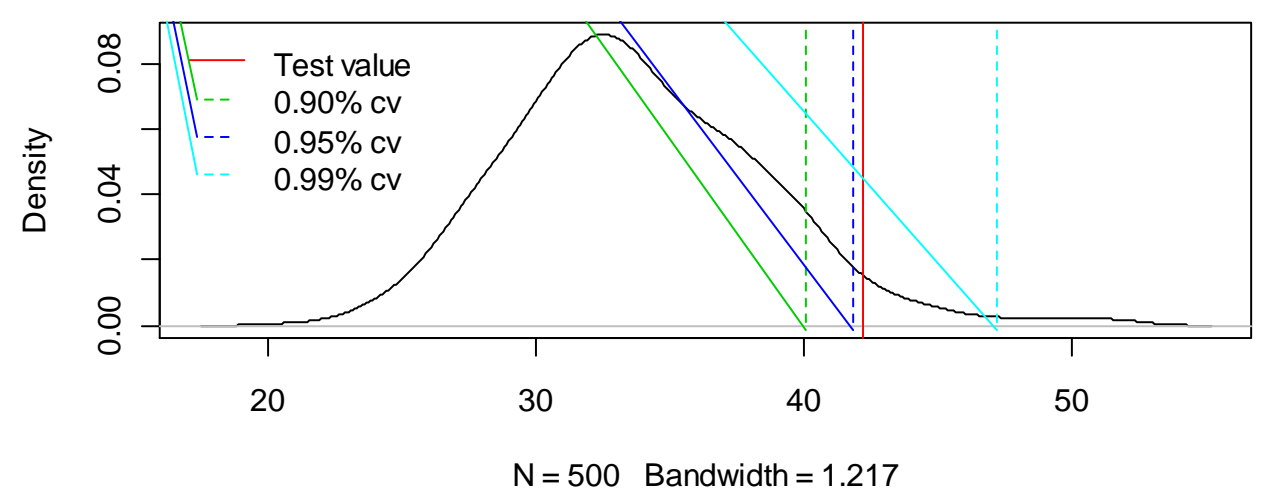

Grid Search
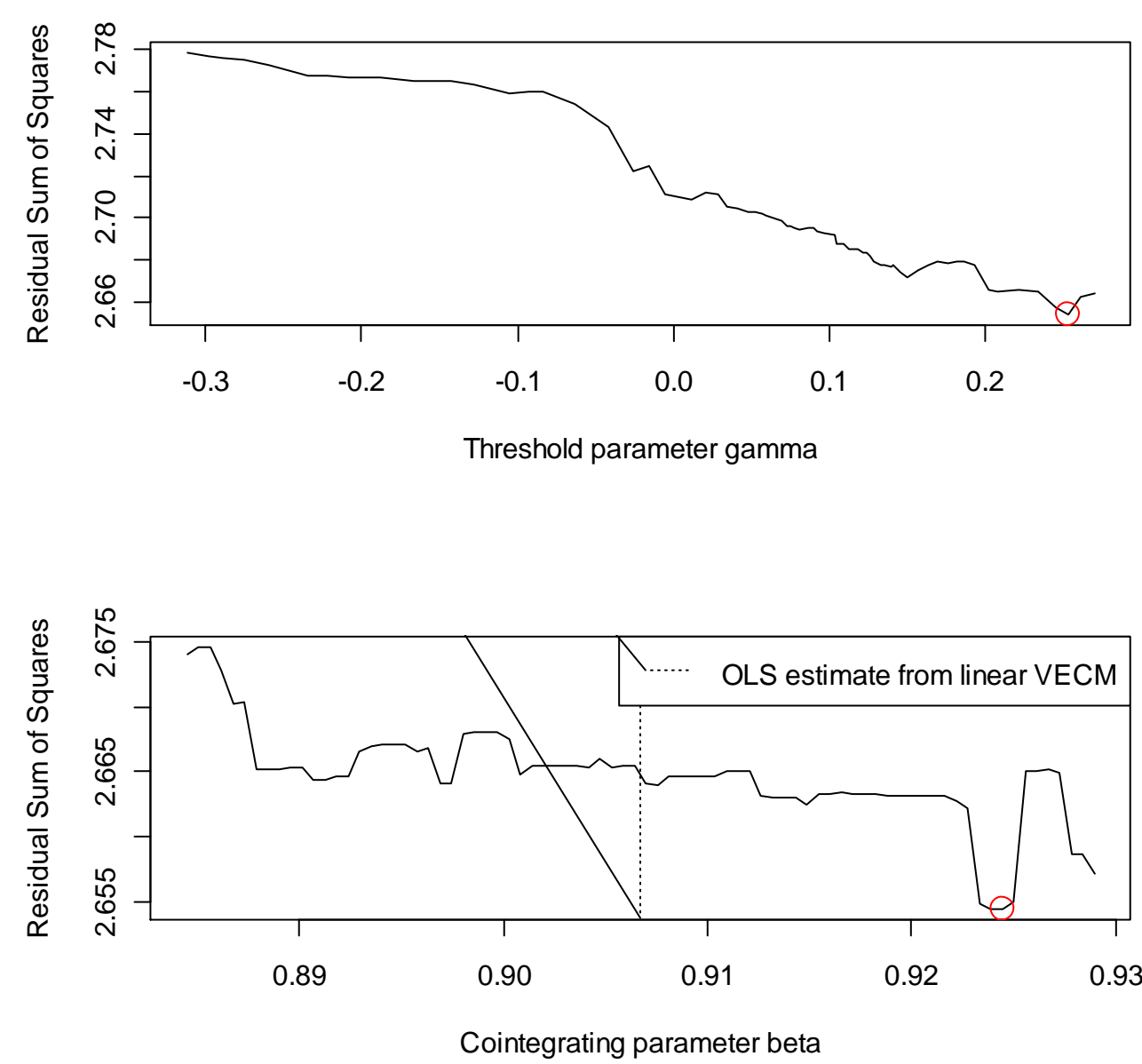

Figure 3: Testing Crude oil-RTS with TVECM (Antonio, et al., 2009; Hansen \& Seo, 2002) 
Table 1: Unit Root tests using the Augmented Dickey-Fuller \& Phillips-Perron

\begin{tabular}{|c|c|c|c|c|}
\hline \multirow{2}{*}{$\begin{array}{l}\text { Variable } \\
\text { (price) }\end{array}$} & \multicolumn{2}{|c|}{$\begin{array}{l}\text { Augmented } \\
\text { Dickey-Fuller }\end{array}$} & \multicolumn{2}{|c|}{ Phillips-Perron } \\
\hline & Drift & Trend & Drift & Trend \\
\hline Crude Oil & -1.98 & -2.00 & -1.96 & -1.98 \\
\hline$\Delta$ Crude Oil & $-34.63 ®$ & & $-34.63 ®$ & \\
\hline CSI300 & -1.96 & -1.70 & -1.97 & -1.71 \\
\hline$\Delta \mathrm{CSI} 300$ & $-34.37 \AA$ & & $-34.37 \AA$ & \\
\hline BSE30 & -2.09 & -2.04 & -2.09 & -2.04 \\
\hline$\triangle \mathrm{BSE} 30$ & $-33.47 \AA$ & & $-33.47 \AA$ & \\
\hline$\overline{\mathrm{RTS}}$ & -1.84 & -1.90 & -1.77 & -1.84 \\
\hline$\Delta \mathrm{RTS}$ & $-29.03 \AA$ & & $-28.88 \AA$ & \\
\hline BVSP & -2.23 & -2.24 & -2.03 & -1.88 \\
\hline$\Delta \mathrm{BVSP}$ & $-33.97 \AA$ & & $-34.59 \AA$ & \\
\hline
\end{tabular}

Lag length for ADF tests are based on SIC.

Maximum Bandwidth for PP tests are decided based on Newey-West (1994)

Critical values are $-2.89(5 \%),-3.49(1 \%)$ with drift only and; $-3.45(5 \%)$, and $-3.49(1 \%)$ for a model with constant and trend; $-1.94(5 \%)$ and $-2.58(1 \%)$ for a pure random walk model (Mackinnon, 1996)

(B) indicates the pure random walk model 
Table 2: Bi-variate Johansen cointegration rank test

\begin{tabular}{|c|c|c|c|c|c|c|}
\hline Crude Oil vs & $\begin{array}{l}\text { Test } \\
\text { statistic } \\
\mathrm{S}\end{array}$ & $\begin{array}{l}\text { Critical } \\
\text { values } \\
\left(\lambda_{0.95}\right)\end{array}$ & Decision & $\begin{array}{l}\text { Test } \\
\text { statistic } \\
\mathrm{S}\end{array}$ & $\begin{array}{l}\text { Critical } \\
\text { values } \\
\left(\lambda_{0.95}\right)\end{array}$ & Decision \\
\hline $\begin{array}{l}\text { CSI300 } \quad(\mathrm{K}=1 ; \quad \text { Criteria: } \\
\text { AIC })\end{array}$ & & Model 2 & & & Model 4 & \\
\hline \multicolumn{7}{|l|}{$\lambda_{\text {trace statistics }}$} \\
\hline$H_{0}: r=0$ vs $H_{1}: r \geq 1$ & 29.41 & 20.26 & Rejected & 28.89 & 25.87 & Rejected \\
\hline$H_{0}: r \leq 1$ vs $H_{1}: r \geq 2$ & 9.33 & $12.76 * * *$ & $\begin{array}{l}\text { Not } \\
\text { rejected }\end{array}$ & 9.32 & 12.52 & $\begin{array}{l}\text { Not } \\
\text { rejected }\end{array}$ \\
\hline \multicolumn{7}{|l|}{$\lambda_{\max \text { statistics }}$} \\
\hline$H_{0}: r=0$ vs $H_{1}: r=1$ & 20.09 & 15.89 & Rejected & 19.63 & 19.39 & Rejected \\
\hline$H_{0}: r \leq 1$ vs $H_{1}: r=2$ & 9.33 & $12.76 * * *$ & $\begin{array}{l}\text { Not } \\
\text { rejected }\end{array}$ & 9.32 & 12.52 & $\begin{array}{l}\text { Not } \\
\text { rejected }\end{array}$ \\
\hline $\begin{array}{l}\text { BSE30 } \quad(\mathrm{K}=1 ; \quad \text { Criteria: } \\
\text { AIC })\end{array}$ & & Model 1 & & & Model 3 & \\
\hline \multicolumn{6}{|l|}{$\lambda_{\text {trace statistics }}$} & Rejected \\
\hline$H_{0}: r \leq 1$ vs $H_{1}: r \geq 2$ & 0.00 & $2.98 *$ & $\begin{array}{l}\text { Not } \\
\text { rejected }\end{array}$ & 8.03 & 3.84 & Rejected \\
\hline \multicolumn{7}{|l|}{$\lambda_{\max \text { statistics }}$} \\
\hline$H_{0}: r=0$ vs $H_{1}: r=1$ & 11.13 & $9.47 *$ & Rejected & 11.04 & 14.26 & $\begin{array}{l}\text { Not } \\
\text { rejected }\end{array}$ \\
\hline$H_{0}: r \leq 1$ vs $H_{1}: r=2$ & 0.00 & $2.98 *$ & - & - & - & - \\
\hline RTS: (K=5; Criteria: AIC ) & & Model 3 & & & Model 5 & \\
\hline $\begin{array}{l}\lambda_{\text {trace statistics }} \\
\quad H_{0}: r=0 \text { vs } H_{1}: r \geq 1\end{array}$ & \multicolumn{5}{|c|}{$\lambda_{\text {trace statistics }}$} & Rejected \\
\hline$H_{0}: r \leq 1$ vs $H_{1}: r \geq 2$ & 7.81 & 3.84 & Rejected & 8.68 & 3.84 & Rejected \\
\hline \multicolumn{7}{|l|}{$\lambda_{\text {max statistics }}$} \\
\hline$H_{0}: r=0$ vs $H_{1}: r=1$ & 11.33 & 14.26 & $\begin{array}{l}\text { Not } \\
\text { rejected }\end{array}$ & 13.08 & 17.15 & Rejected \\
\hline$H_{0}: r \leq 1$ vs $H_{1}: r=2$ & - & - & - & - & - & $\begin{array}{l}\text { not } \\
\text { rejected }\end{array}$ \\
\hline BVSP $(\mathrm{K}=1$; Criteria: AIC $)$ & & Model 1 & & & Model 4 & \\
\hline $\begin{array}{l}\lambda_{\text {trace statistics }} \\
\quad H_{0}: r=0 \text { vs } H_{1}: r \geq 1\end{array}$ & 15.39 & 12.32 & Rejected & 24.12 & 19.39 & Rejected \\
\hline$H_{0}: r \leq 1$ vs $H_{1}: r \geq 2$ & 0.13 & 4.13 & $\begin{array}{l}\text { Not } \\
\text { rejected }\end{array}$ & 11.44 & 12.52 & $\begin{array}{l}\text { Not } \\
\text { rejected }\end{array}$ \\
\hline \multicolumn{7}{|l|}{$\lambda_{\text {max statistics }}$} \\
\hline$H_{0}: r=0$ vs $H_{1}: r=1$ & 15.26 & 11.22 & Rejected & 24.12 & 19.39 & Rejected \\
\hline
\end{tabular}




$$
\begin{array}{l|lll|lll}
H_{0}: r \leq 1 \text { vs } H_{1}: r=2 & 0.13 & 4.13 & \begin{array}{l}
\text { Not } \\
\text { rejected }
\end{array} & 11.44 & 12.52 & \begin{array}{l}
\text { Not } \\
\text { rejected }
\end{array}
\end{array}
$$

Model 1-no intercept and no deterministic trend

Model 2-no deterministic trend (restricted constant)

Model 3-Linear deterministic trend model

Model 4-allows linear trend in the cointegrating space

Model 5-allows linear trend in the cointegrating space and intercept in VAR

* Indicates the $10 \%$ probability level

*** Indicates the $1 \%$ probability level 
Table 3: Estimates of long-run \& the speed of adjustment from ECM

\begin{tabular}{llll}
\hline \multirow{2}{*}{ Model } & Regressors & $\begin{array}{l}\text { Parameter } \\
\text { estimates }\end{array}$ & t-test \\
\hline \multirow{2}{*}{ Crude oil-CSI300 $^{4}$} & $\beta$ & -0.05 & -0.81 \\
& ECT $_{\mathrm{t}-1}$ & -0.11 & -3.94 \\
\hline \multirow{2}{*}{ Crude oil- BSE30 $^{1}$} & $\beta$ & -0.79 & -15.05 \\
& $\mathrm{ECT}_{\mathrm{t}-1}$ & -0.01 & -3.29 \\
\hline \multirow{2}{*}{ Crude oil-RTS $^{3}$} & $\beta$ & -0.34 & -1.67 \\
& $\mathrm{ECT}_{\mathrm{t}-1}$ & -0.01 & -2.47 \\
\hline \multirow{2}{*}{ Crude oil-BVSP $^{4}$} & $\beta$ & -1.53 & -6.18 \\
& $\mathrm{ECT}_{\mathrm{t}-1}$ & -0.02 & -4.91
\end{tabular}

$1,3,4$ indicates that the results are derived from model 1, 3, 4 respectively 
Table 4: Causality from Johansen VECM (weak exogeneity test)

\begin{tabular}{|c|c|c|c|}
\hline \multirow[t]{2}{*}{ Models } & \multicolumn{3}{|c|}{ Causality test } \\
\hline & $\mathrm{A}$ & B & Causality Decision \\
\hline Crude oil-CSI300 & $\begin{array}{l}5.23 \\
(0.01)\end{array}$ & $\begin{array}{l}7.84 \\
(0.00) \\
\end{array}$ & Crude Oil $\leftrightarrow$ CSI300 \\
\hline Crude oil- BSE30 ${ }^{1}$ & $\begin{array}{l}8.54 \\
(0.00)\end{array}$ & $\begin{array}{l}2.17 \\
(0.11)\end{array}$ & Crude Oil $\rightarrow$ BSE30 \\
\hline Crude oil-RTS ${ }^{3}$ & $\begin{array}{l}4.82 \\
(0.00) \\
\end{array}$ & $\begin{array}{l}5.88 \\
(0.00) \\
\end{array}$ & Crude Oil $\leftrightarrow$ RTS \\
\hline Crude oil-BVSP ${ }^{4}$ & $\begin{array}{l}13.53 \\
(0.00) \\
\end{array}$ & $\begin{array}{l}3.18 \\
(0.02) \\
\end{array}$ & Crude Oil $\leftrightarrow$ BVSP \\
\hline
\end{tabular}

A indicates $\mathrm{H}_{0}: \alpha_{1}=0$ vs $\mathrm{H}_{1}: \alpha_{1} \neq 0$

B indicates $\mathrm{H}_{0}: \alpha_{2}=0$ vs $\mathrm{H}_{1}: \alpha_{2} \neq 0$

Parentheses indicate the probability level

$1,3,4$ indicates that the results are derived from model $1,3,4$ respectively

$\rightarrow$ indicates unidirectional causality

$\leftrightarrow$ indicates bi-directional causality 